\title{
Microzooplankton grazing in northern San Francisco Bay measured by the dilution method
}

\author{
M. C. Murrell ${ }^{1, *}$, J. T. Hollibaugh ${ }^{2, * *}$ \\ ${ }^{1}$ Department of Ocean Sciences, University of California, Santa Cruz, California 95064, USA \\ ${ }^{2}$ Romberg Tiburon Center, San Francisco State University, PO Box 855, Tiburon, California 94926, USA
}

\begin{abstract}
Microzooplankton (defined herein as phagotrophs $<200 \mu \mathrm{m}$ ) grazing was studied in northern San Francisco Bay, California, USA, from September 1993 to July 1994 using the dilution method. The focus of the study was the estuarine turbidity maximum zone of northern San Francisco Bay (Suisun Bay), though some experiments were also performed in southern San Francisco Bay and Tomales Bay. Three microzooplankton prey items were examined: phytoplankton (as chlorophyll a), cyanobacteria, and bacterioplankton (i.e. non-chlorophyll containing bacteria). Statistically significant grazing rates were observed in 5 of 31 northern San Francisco Bay experiments over 7 dates spanning 10 mo. Average grazing rates on phytoplankton, cyanobacteria and bacterioplankton were $0.06,0.00$, and $0.22 \mathrm{~d}^{-1}$ respectively. Grazing rates were statistically significant in 5 of 7 southern San Francisco Bay experiments on 3 dates. Average grazing rates on phytoplankton and cyanobacteria were 0.41 and $1.84 \mathrm{~d}^{-1}$ respectively. Grazing rates were statistically significant in 4 of 4 Tomales Bay experiments performed on 1 date, averaging 0.69 and $0.75 \mathrm{~d}^{-1}$ on phytoplankton and bacterioplankton respectively. The low grazing rates in northern San Francisco Bay suggest that microzooplankton may not play a pivotal role in controlling prey biomass, although this interpretation is complicated by the possibility that one or more of the dilution method assumptions may not hold in this environment. We hypothesize that the introduced Asian clam Potamocorbula amurensis may be controlling the biomass of microzooplankton, their prey, or both. A review of the literature indicated that the dilution method regularly yields statistically non-significant grazing rates, suggesting that our results are not unique.
\end{abstract}

KEY WORDS: Dilution technique - San Francisco Bay · Estuary - Microzooplankton · Trophic coupling

\section{INTRODUCTION}

The importance of the microbial loop (Pomeroy 1974, Azam et al. 1983), including the microzooplankton and nanozooplankton (phagotrophs $<200 \mu \mathrm{m}$ ), has been well established in many aquatic habitats (review: Sherr \& Sherr 1994). Three functions which are typically attributed to microzooplankton and nanozooplankton are: (1) remineralizing organic matter and nutrients (Goldman \& Caron 1985, Goldman et al. 1985); (2) controlling biomass of bacteria and phytoplankton (Fenchel 1982, McManus \& Fuhrman 1988); and (3) providing a link to higher trophic levels (Sherr

\footnotetext{
•E-mail: murrell@biology.ucsc.edu

- Present address: Department of Marine Science, University of Georgia, Athens, Georgia 30602-3636, USA
}

et al. 1986, Stoecker \& Capuzzo 1990). As a result, these grazers can be critically important mediators of matter and energy transfer in aquatic systems.

There is tremendous taxonomic diversity within the functionally defined groupings of microzooplankton and nanozooplankton. Microzooplankton typically refers to heterotrophs from 20 to $200 \mu \mathrm{m}$ in greatest dimension and includes diverse taxa from small metazoans such as copepod nauplii and rotifers, to ciliates (including loricate and aloricate forms) and heterotrophic dinoflagellates. Microzooplankton can be effective consumers of prey as small as bacteria to organisms nearly as large as themselves (Lessard 1991, Sherr \& Sherr 1994). Nanozooplankton are smaller grazers, from 2 to $20 \mu \mathrm{m}$ in size, and are mostly flagellated protozoans. The diets of nanozooplankton tend to be more restricted to bacteria sized organisms (Sherr \& 
Sherr 1994). For simplicity we will lump these 2 categories and refer to the entire assemblage as microzooplankton.

There is little information on microzooplankton in San Francisco Bay, CA, USA. Ambler et al. (1985) reported abundances of net-collected microzooplankton and found abundance peaks of tintinnid ciliates, Eutintinnus neriticus, Tintinnopsis sp., of the rotifer Synchaeta sp. and of copepod nauplii in northern San Francisco Bay during the summer of 1980, coinciding with a phytoplankton bloom. Maximum abundance of most groups occurred in San Pablo Bay, and most were much less abundant in Suisun Bay. Combined abundances of these relatively large $(>100 \mu \mathrm{m})$ and robust organisms peaked at about $100 \mathrm{l}^{-1}$. While their grazing impacts on bacteria and phytoplankton are not known, their high abundances imply potential significance, especially on the community of larger phytoplankton. No published information exists on abundance of small (5 to $20 \mu \mathrm{m}$ ) heterotrophic flagellates, although data from other aquatic systems suggest at least $1000 \mathrm{ml}^{-1}$ (Berninger et al. 1991, Sanders et al. 1992), and these could be an important sink for bacterial production.

The focus of this study was to examine the importance of microzooplankton grazing in northern San Francisco Bay (North Bay) using the dilution method (Landry \& Hassett 1982). Additional dilution experiments were done in nearby southern San Francisco Bay (South Bay) and Tomales Bay to provide a contrast and as a test of our experimental method. These 3 locations represent a gradient in primary production from very low in the North Bay, intermediate and highly episodic in South Bay, to very high in Tomales Bay. The dilution method has been applied in a wide variety of environments to measure microzooplankton grazing with a focus on both predator control of prey biomass as well as more subtle predator-prey interactions. Of particular interest to our study was the role of microzooplankton in controlling the biomass of their prey. One feature of this method, if all assumptions are satisfied, is that it does not rely on abundance estimates of different groups of grazers, but integrates the net grazing impact of the entire grazer community. We chose this method over other available methods such as uptake or disappearance of fluorescently labeled bacteria and algae because of the difficulty of enumerating labeled particles by microscopy in particle-rich environments.

\section{MATERIALS AND METHODS}

Dilution method theory and practice. The strength of the dilution method is its ability to partition a net change in prey abundance into 2 additive components: the microzooplankton grazing rate $(g)$ and prey growth rate $(k)$. The dilution method is based on 3 assumptions as discussed in detail by Landry \& Hassett (1982): (1) specific growth rate of prey is not density dependent, (2) predation is a direct linear function of prey abundance, and (3) prey growth can be adequately represented by the exponential growth equation. Additionally, the population growth rate of consumers and prey is assumed to be constant across treatments. The generalized exponential model is:

$$
N_{t}=N_{0} \mathrm{e}^{(k-g) t}
$$

where $N_{t}$ is the density of the prey population at time $t_{\text {, }}$ $N_{0}$ is the density of the prey population at time zero, $k$ is the prey population growth rate, and $g$ is the prey population mortality rate due to grazing.

In practice, a dilution experiment consists of a series of bottle incubations in which the proportions of filtered and whole water are varied to make dilution treatments. In bottles which have been diluted with filtered, cell-free water, prey populations experience reduced grazing (hence increased net growth) in proportion to the degree of dilution, while the specific growth rate of the prey is not affected. Net population growth rates in each bottle are measured by sampling before and after an incubation period (usually $24 \mathrm{~h}$ ) and are calculated as the change in the natural log prey concentration per unit time. The positive response of net population growth rate due to relaxed grazing pressure (as a function of dilution) is a measure of the grazing rate. In this study, phytoplankton concentration was estimated by chlorophyll $a$ and both cyanobacteria and bacterioplankton (non-chlorophyllcontaining bacteria) abundance was measured by direct counts using epifluorescence microscopy.

In order to calculate apparent growth rates of prey in each bottle, the exponential growth equation was converted into a linear model by log transformation and rearrangement:

$$
\ln \left(N_{t}\right)=(k-g) t+\ln \left(N_{0}\right)
$$

In this form, apparent growth rate $(k-g)$ was calculated as the slope of the linear regression of natural log prey concentration versus time. Phytoplankton apparent growth rates were calculated from triplicate analyses of chlorophyll concentration per bottle per time point $t_{i}$ bacterial apparent growth rates were calculated from a single sample enumeration per bottle per time point. This method of calculating apparent growth rates weights each measurement in the regression analysis equally and allows for variable numbers of replicates and time points.

The apparent growth rate estimates (1 from each incubation bottle) were in turn plotted as a function of 
dilution $(X)$ using:

$$
1 / t \ln \left(N t / N_{0}\right)=-g X+k
$$

and regression analysis of these data yielded slope and intercept values corresponding to microzooplankton grazing $(-g)$ and prey growth $(k)$ respectively. The degree of dilution of each treatment was determined by dividing the measured prey concentration by the concentration in the undiluted treatment. A significant negative slope (1-tailed t-test, $\mathrm{p}<0.05)$ suggested measurable grazer control on prey concentration. The prey growth rate was estimated by extrapolating the regression to the $y$-intercept. If the slope was not significantly less than zero, then grazing was assumed to be zero. In this case prey population growth rates were calculated only from undiluted treatments (whole water) because the undiluted treatments were subjected to the fewest manipulations and additional assumptions concerning the effect of dilution need not be made.

Study sites and sampling procedures. San Francisco Bay (Fig. 1A) is one of the largest estuaries on the west coast of the United States and is comprised of 2 connected but physically distinct systems. The North Bay is a net heterotrophic estuarine system characterized by low phytoplankton production $(39 \mathrm{~g}$ $\mathrm{C} \mathrm{m}^{-2} \mathrm{yr}^{1}$; Alpine \& Cloern 1992) and bacterial production which can equal or exceed primary production (Hollibaugh \& Wong 1996). Phytoplankton blooms were a normal summer-time occurrence in the North Bay prior to 1986, but have since ceased to occur (Alpine \& Cloern 1992). This shift has been strongly linked to the introduction and rapid establishment of the Asian clam Potamocorbula amurensis which has filtration rates capable of clearing the entire water column on a daily basis and thus prevents accumulation of phytoplank-

Fig. 1. Map of San Francisco Bay, CA, USA, showing station locations where dilution experiments were performed. (A) San Francisco Bay, (B) Tomales Bay
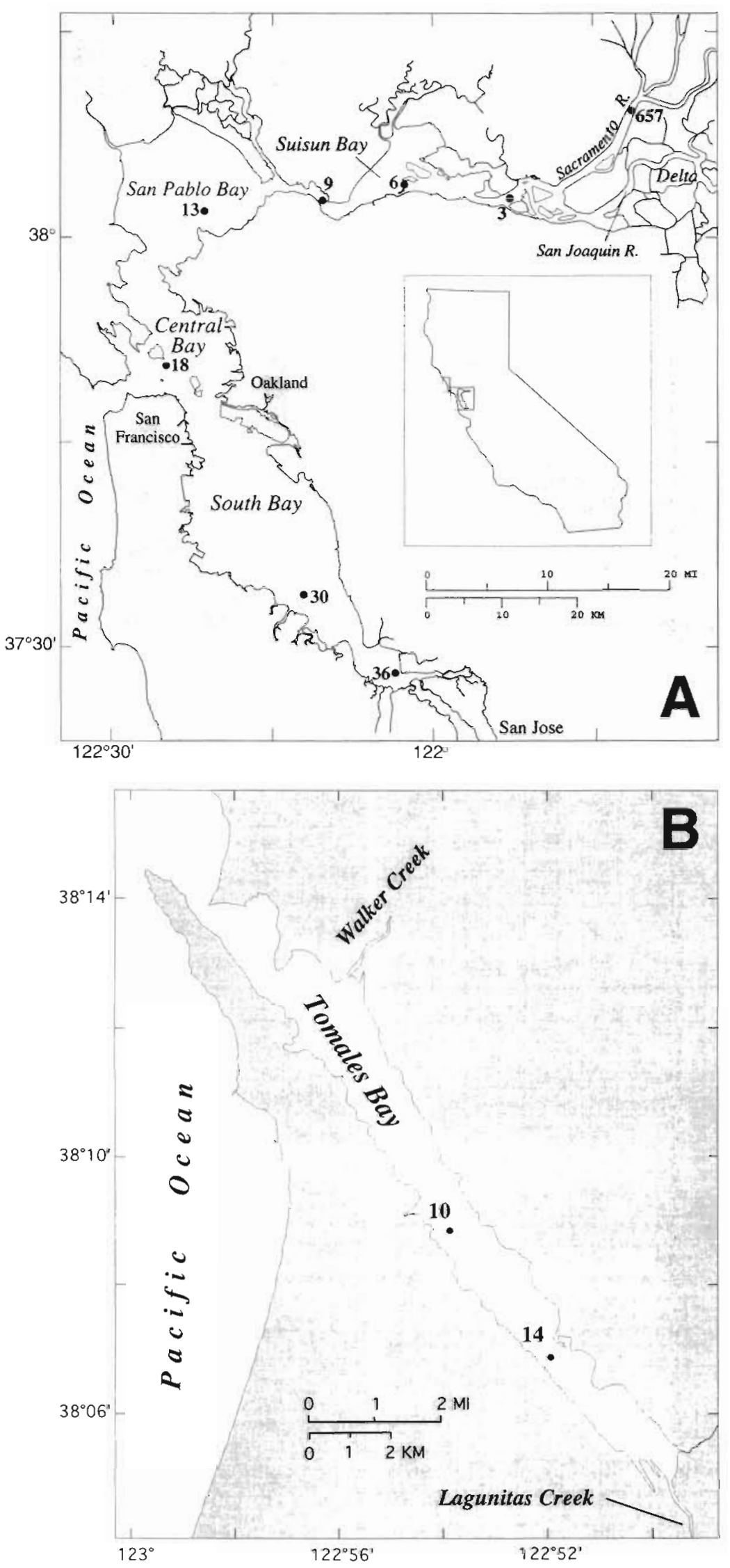
ton biomass (Alpine \& Cloern 1992, Cole et al. 1992, Werner \& Hollibaugh 1993). South San Francisco Bay, in contrast, is a lagoonal system and supports higher annual phytoplankton production (150 $\mathrm{g} \mathrm{C} \mathrm{m}^{-2} \mathrm{yr}^{-1}$; Cole \& Cloern 1987) primarily because of a strong spring bloom, the timing and intensity of which have been well studied and modeled (Cloern et al. 1985, Cole \& Cloern 1987, Cloern 1991). Although $P$. amurensis has become established in the South Bay as well, it has not prevented the development of spring blooms. Tomales Bay is a relatively pristine, productive (300 $\mathrm{g} \mathrm{C} \mathrm{m}^{-2} \mathrm{yr}^{-1}$; Cole 1989) coastal embayment located about $50 \mathrm{~km}$ north of San Francisco (Fig. 1B). While data from the South Bay and Tomales Bay are included for comparison, the focus of this study was the North Bay.

Dilution experiments were conducted on 12 dates from September 1993 to August 1994. In the North Bay, grazing experiments were conducted with samples from a station in the channel of Suisun Bay on 6 dates, although on 1 date experiments were conducted at 6 stations (including Suisun Bay) along the estuarine gradient from the Central Bay to the Sacramento River. Grazing experiments were conducted in the South Bay on 3 dates at 2 stations and on 1 date at 2 stations in Tomales Bay. The San Francisco Bay experiments were conducted aboard the United States Geological Survey (USGS) research vessel 'Polaris', and at the Tomales Bay experiments were conducted at Land Margin Ecosystem Research (LMER) field laboratory at Marshall, CA.

Before each experiment, all apparatus that came in contact with the sample water was cleaned with laboratory detergent, rinsed with deionized water, soaked in $1 \mathrm{~N} \mathrm{HCl}$ for a minimum of several hours (usually over night), and thoroughly rinsed with deionized water. Before use, the bottles and filtration apparatus were further rinsed with sample water. All experiments were conducted with surface water collected using a polyethylene bucket and stored in polyethylene cubitainers. A portion of the water was filtered sequentially through acrylic filtration units $(142 \mathrm{~mm}$ diameter) fitted with a $1.0 \mu \mathrm{m}$ glass fiber filter and a $0.2 \mu \mathrm{m}$ pore size cellulose acetate filter in a closed system to minimize exposure to airborne contaminants. The filtrate was mixed with unfiltered water to make dilution treatments targeted at 10,30,70 and 100\% (whole water) which were then distributed into $1 \mathrm{l}$ square polycarbonate bottles. Initial samples were taken from the remaining dilution water. Chlorophyll was measured for every experiment, while cyanobacteria and bacterioplankton were enumerated less frequently. Bottles were screened to ca $50 \%$ ambient light to approximate in situ light conditions and were incubated at ambient temperature using a running seawater incubator while under way, or suspended overboard in a mesh bag while docked at night. Often 1 bottle from each treatment was enclosed in a heavy black plastic bag as a dark control (September, October, and November 1993 and May 1994, 2 replicates). After ca $24 \mathrm{~h}$ a water sample was removed from each bottle for chlorophyll, bacteria and nutrient analysis. From September to December 1993, incubations were continued for an additional $24 \mathrm{~h}$, at which time the final samples were taken.

Hydrographic data were collected by the USGS using a Seabird CTD system which recorded temperature, salinity, fluorescence and optical backscatter. The latter 2 sensors were routinely calibrated against environmental samples to estimate chlorophyll a and suspended particulate matter, respectively. Samples for nutrient analyses $\left(\mathrm{NH}_{4}{ }^{+}, \mathrm{NO}_{2}{ }^{-}\right.$and $\left.\mathrm{NO}_{3}{ }^{-}\right)$were taken at initial and final time points and frozen immediately. Analyses were run within 2 mo on a Technicon II autoanalyzer. Ammonium was measured by the salicylatehypochlorite method (Bower \& Holm-Hansen 1980) as modified for automated analysis (Hager 1993). Nitrate $\left(\mathrm{NO}_{3}{ }^{-}+\mathrm{NO}_{2}{ }^{-}\right)$was analyzed using the automated cadmium reduction method (Hager 1993).

For chlorophyll, triplicate water samples of 50 to $150 \mathrm{ml}$ were filtered through Whatman GF/F filters, frozen and returned to the lab. Filters were extracted at $-20^{\circ} \mathrm{C}$ overnight in $90 \%$ acetone, centrifuged and the extract fluorescence was measured on a Turner Designs Model 10 fluorometer calibrated for chlorophyll a (Strickland \& Parsons 1972).

Samples for microscopy were preserved with either $1 \%$ cacodylate buffered glutaraldehyde or $2 \%$ borate buffered formaldehyde and stored at $4^{\circ} \mathrm{C}$. Samples were stained with Acridine Orange (AO) or DAPI, filtered onto black polycarbonate membrane filters, and enumerated using a Zeiss Axiophot epifluorescence microscope (Hobbie et al. 1977, Porter \& Feig 1980).

Cyanobacteria were counted within 2 wk at $630 \times$ using a green excitation filter (510 nm band pass) and a red emission filter (590 $\mathrm{nm}$ long pass). Cyanobacteria fluoresced an intense red color and background fluorescence was very low. A minimum of 5 reticule fields were counted and ca 200 to 300 cells were enumerated. For a few samples that had very low abundance, cell counts were accumulated over a minimum of 20 reticule fields.

Bacterioplankton were stained with either AO (San Francisco Bay) or DAPI (Tomales Bay) and viewed using standard blue or UV filter sets respectively. Tomales Bay samples were counted within a few days; San Francisco Bay samples were counted about a year after the experiment. For most counts, a minimum of 10 reticule fields were scanned and 300 cells were enumerated. For a few samples with very low 
abundance, a minimum of 20 reticule fields were counted.

Samples (usually $1 \mathrm{ml}$ ) for total nanoflagellates $(<20 \mu \mathrm{m})$ were stained with $\mathrm{AO}$, filtered onto black polycarbonate membrane filters, and enumerated at $500 x$ under blue excitation. A minimum of 24 microscope fields or 50 cells were enumerated. Because of the low sample volumes necessitated by the high particle loads in Suisun Bay samples, we were not successful at enumerating the larger, less abundant organisms.

In general, it was difficult to enumerate bacterioplankton and nanoflagellates by epifluorescence microscopy in the turbid waters of San Francisco Bay. Developing a reliable protocol caused delays in sample processing. We had better success with AO 150 to $100 \mu \mathrm{g} \mathrm{ml}^{-1}$ ) than with DAPI and we used very small volumes of water $(0.5$ to $1 \mathrm{ml}$ distributed onto $23 \mathrm{~mm}$ diameter filter area) in order to avoid obscuring organisms with particles and also to minimize background fluorescence of the sediment.

\section{RESULTS}

\section{Characterization of study sites}

Water quality variables for all locations and dates are summarized in Table 1 . Temperature and salinity val- ues reflect normal seasonal variation. In Suisun Bay, chlorophyll concentration averaged $1.2 \mathrm{\mu g} \mathrm{l}^{-1}$ (range 0.4 to $2.0 \mathrm{\mu g} \mathrm{l}^{-1}$ ) with no apparent seasonal pattern and dissolved inorganic nitrogen (DIN, $\mathrm{NH}_{4}+\mathrm{NO}_{3}+\mathrm{NO}_{2}$ ) was well above $20 \mu \mathrm{M}$ throughout the study period Suspended particulate material (SPM) averaged $33 \mathrm{mg}$ $\mathrm{l}^{-1}$ and ranged from 7 to $53 \mathrm{mg} \mathrm{l}^{-1}$. Bacterioplankton averaged $1.8 \times 10^{6}$ cells $\mathrm{ml}^{-1}$ (range 1.5 to 2.3 ), which may underestimate true abundance because of cell loss due to sample storage (Turley \& Hughes 1992, 1994, Gundersen et al. 1996). Cyanobacteria abundance averaged $64 \times 10^{3} \mathrm{ml}^{-1}$ (range 39 to 87 ). Total nanoflagellates (autotrophic plus heterotrophic) averaged $1.6 \times 10^{3}$ cells $\mathrm{ml}^{-1}$ (range 0.53 to 2.3 ). Abundances of ciliates (loricate and aloricate), rotifers, and copepod nauplii in Suisun Bay were below our detection limit of approximately $50 \mathrm{l}^{-1}$.

In the South Bay, chlorophyll concentrations were generally higher than in Suisun Bay, averaging $4.6 \mu \mathrm{g}$ $\mathrm{l}^{-1}$, but were highly variable because of the spring bloom (range 2.8 to $16 \mu \mathrm{gl}^{-1}$ ). DIN was also high except during the bloom when it dropped below $5 \mu \mathrm{M}$. SPM averaged $50 \mathrm{mg} \mathrm{l}^{-1}$ and ranged from 4 to $152 \mathrm{mg}$ $1^{-1}$. In Tomales Bay, on the 1 date studied, chlorophyll concentration averaged $6.3 \mu \mathrm{g} \mathrm{^{-1 }}$ across both stations. Suspended particulates averaged $15 \mathrm{mg} \mathrm{l}^{-1}$ and DIN averaged $0.3 \mu \mathrm{M}$, which was much lower than in San Francisco Bay.

Table 1. Summary of surface water hydrography coincident with dilution experiments including temperature (Temp), salinity (Sal), suspended particulate matter (SPM), chlorophyll a (Chlor), dissolved inorganic nitrogen (DIN, $\mathrm{NO}_{3}+\mathrm{NO}_{2}+\mathrm{NH}_{4}$ ), bacterial abundance (Bact), cyanobacterial abundance (Cyano) and total nanoflagellate abundance (Flag)

\begin{tabular}{|c|c|c|c|c|c|c|c|c|c|c|}
\hline Location & Stn & Date & $\begin{array}{l}\text { Temp } \\
\left({ }^{\circ} \mathrm{C}\right)\end{array}$ & $\begin{array}{c}\text { Sal } \\
\text { (psu) }\end{array}$ & $\begin{array}{c}\text { SPM } \\
\left(\mathrm{mg} \mathrm{l}^{-1}\right)\end{array}$ & $\begin{array}{c}\text { Chlor } \\
\left(\mu \mathrm{g} \mathrm{L}^{-1}\right)\end{array}$ & $\begin{array}{l}\text { DIN } \\
(\mu \mathrm{M})\end{array}$ & $\begin{array}{c}\text { Bact } \\
\left(10^{6} \mathrm{ml}^{-1}\right)\end{array}$ & $\begin{array}{c}\text { Cyano } \\
\left(10^{3} \mathrm{ml}^{-1}\right)\end{array}$ & $\begin{array}{c}\text { Flag } \\
\left(10^{3} \mathrm{ml}^{-1}\right)\end{array}$ \\
\hline \multirow[t]{7}{*}{ Suisun Bay } & \multirow[t]{7}{*}{6} & 8 Sep 1993 & 20.8 & 4.7 & 24 & 0.4 & 27 & 1.7 & 87 & 1.9 \\
\hline & & 6 Oct 1993 & 17.8 & 8.2 & 20 & 0.7 & 37 & 2.3 & 65 & 2.3 \\
\hline & & 8 Nov 1993 & 16.7 & 9.2 & 7 & 1.0 & 44 & 1.6 & 39 & 1.8 \\
\hline & & 7 Dec 1993 & 11.1 & 9.7 & 38 & 0.9 & 29 & 2.1 & & 0.53 \\
\hline & & 17 Mar 1994 & 14.3 & 3.1 & 53 & 2.0 & & 1.9 & & 2.3 \\
\hline & & 19 Apr 1994 & 18.0 & 3.5 & 52 & 1.4 & 48 & 1.7 & & 1.1 \\
\hline & & 17 May 1994 & 18.3 & 2.2 & 42 & 1.8 & 43 & 1.5 & 120 & 1.3 \\
\hline Central Bay & 18 & 19 Apr 1994 & 14.9 & 27.7 & 7 & 3.7 & 24 & & & \\
\hline San Pablo Bay & 13 & 19 Apr 1994 & 17.0 & 19.4 & 11 & 2.3 & 34 & & & \\
\hline Carquinez Strait & 9 & 19 Apr 1994 & 17.0 & 10.1 & 47 & 1.5 & 53 & & & \\
\hline Chipps Island & 3 & 19 Apr 1994 & 18.0 & 0.7 & 31 & 3.1 & 43 & & & \\
\hline Sacramento River & 657 & 19 Apr 1994 & 18.5 & 0.1 & 12 & 2.6 & 38 & & & \\
\hline \multirow[t]{5}{*}{ South Bay } & 30 & 9 Mar 1994 & 14.6 & 26.6 & 4 & 16.0 & 4 & \multirow{3}{*}{\multicolumn{3}{|c|}{1}} \\
\hline & & 15 Apr 1994 & 17.3 & 25.5 & 30 & 3.8 & 47 & & & \\
\hline & & 18 Aug 1994 & 21.7 & 31.3 & 21 & 3.3 & 21 & & & \\
\hline & 36 & 15 Apr 1994 & 17.7 & 21.7 & 152 & 6.0 & 140 & \multirow{2}{*}{\multicolumn{2}{|c|}{20}} & \\
\hline & & 18 Aug 1994 & 22.8 & 29.4 & 45 & 2.8 & 35 & & & \\
\hline \multirow[t]{2}{*}{ Tomales Bay } & 10 & 11 Jul 1994 & 18.7 & 34.3 & 20 & 7.3 & 0.2 & 3.2 & \multirow{2}{*}{\multicolumn{2}{|c|}{18}} \\
\hline & 14 & $11 \mathrm{Jul} 1994$ & 20.8 & 35.0 & 9 & 5.3 & 0.3 & 6.5 & & \\
\hline
\end{tabular}




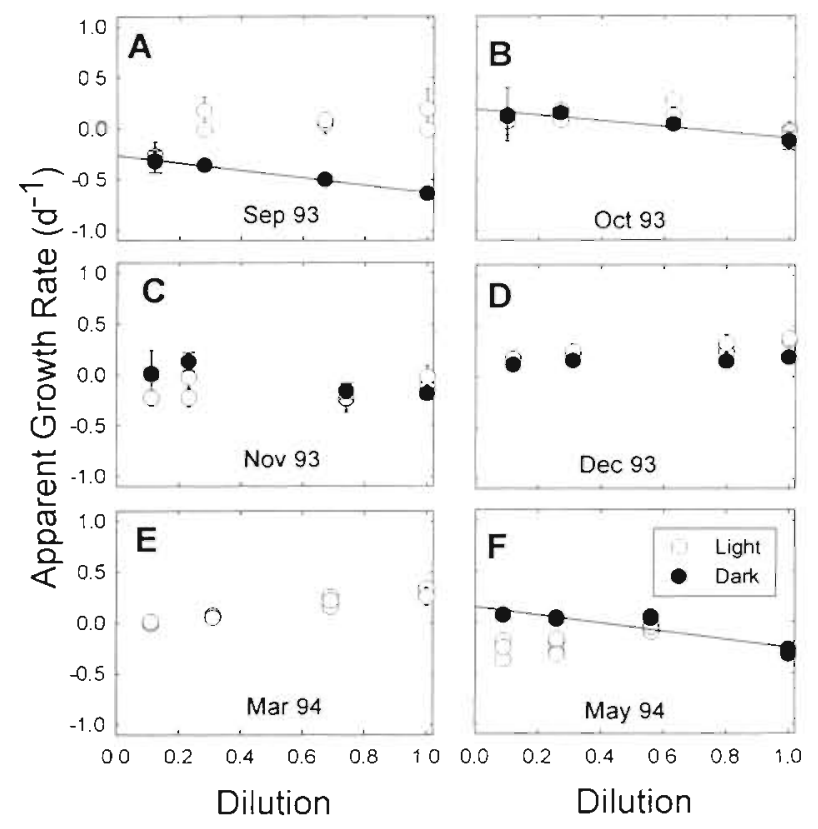

Fig. 2. Dilution plots showing grazing on phytoplankton as measured by chlorophyll $a$ in Suisun Bay. Open symbols and dashed regression lines represent data from light-exposed incubations. Solid symbols and solid regression lines represent dark incubations. Error bars, which represent 1 standard error, do not appear on plots when smaller than the symbol. Lines were plotted only if the slope of the regression was statistically significant by $t$-test, $p<0.05$. (A) 8 September 1993 , (B) 6 October 1993, (C) 8 November 1993, (D) 7 December 1993, (E) 17 March 1994, and (F) 17 May 1994

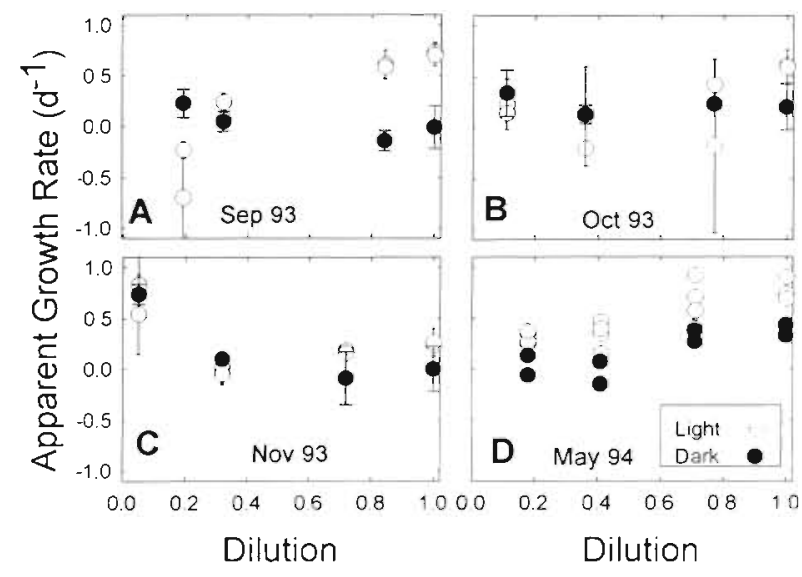

Fig. 3. Dilution plots showing grazing on cyanobacteria as measured by direct counts in Suisun Bay. Other details as in Fig. 2. (A) 8 September 1993, (B) 6 October 1993, (C) 8 November 1993, (D) 17 May 1994 (no error bars)

\section{Grazing experiments}

Grazing results are summarized in Figs. 2 to 7 , which show the relationship between the fraction of unfiltered seawater (i.e. dilution) versus the apparent

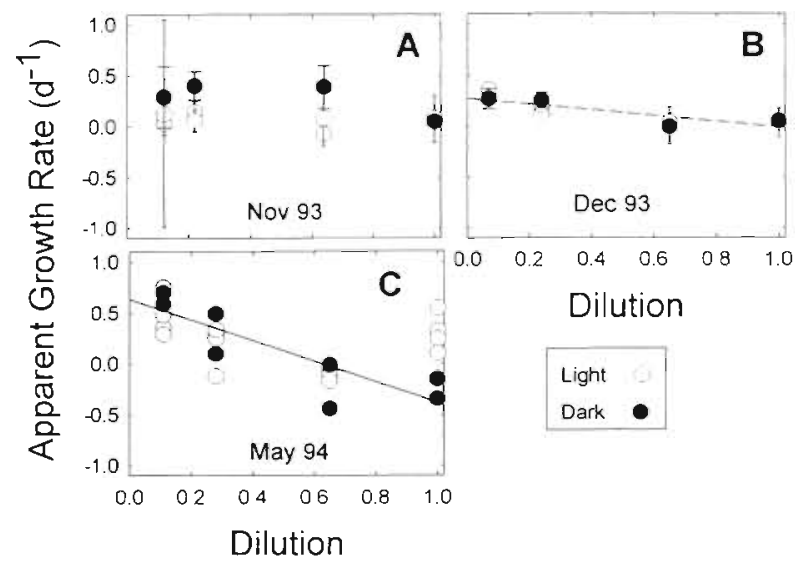

Fig. 4. Dilution plots showing grazing on bacterioplankton as measured by direct counts in Suisun Bay. Other details as in Fig. 2. (A) 8 November 1993, (B) 7 December 1993, and (C) 17 May 1994 (no error bars)

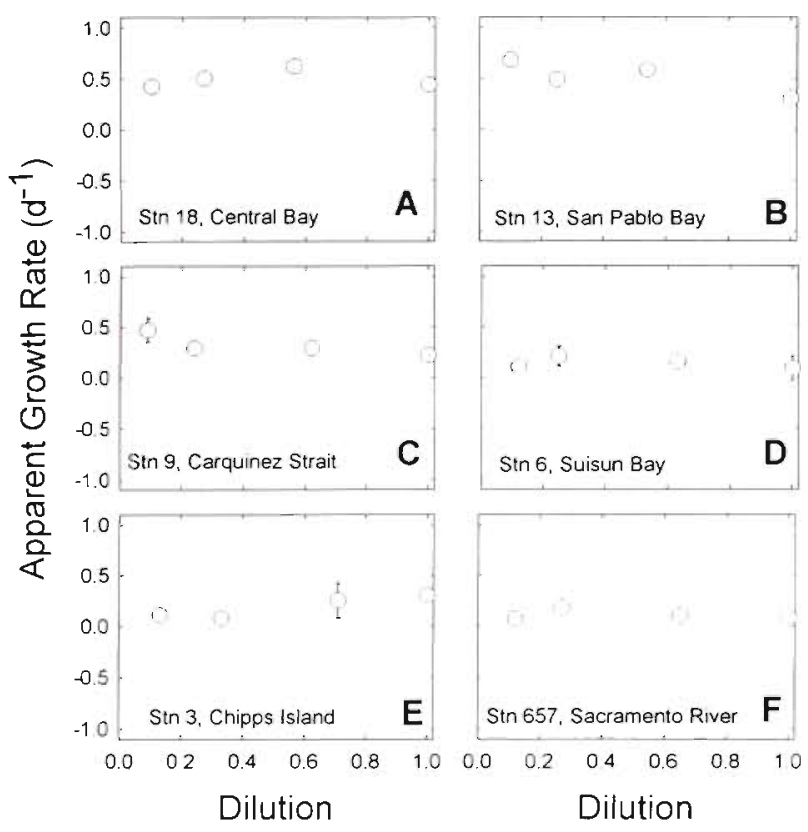

Fig 5. Dilution plots showing grazing on phytoplankton as measured by chlorophyll a at 6 north San Francisco Bay stations on 19 April 1994. Other details as in Fig. 2. (A) Stn 18, Central Bay; (B) Stn 13, San Pablo Bay; (C) Stn 9, Carquinez Strait; (D) Stn 6, Suisun Bay; (E) Stn 3, Chipps Island; (F) Stn 657, Sacramento River

growth rate of the prey. In Suisun Bay, grazing on phytoplankton was statistically significant on 3 of the 7 dates measured (September and October 1993, May 1994), and in each case, only the dark treatments were significant (Fig. 2, Table 2). Grazing rates, when significantly greater than zero, ranged from 0.28 to $0.37 \mathrm{~d}^{-1}$ and growth rates (based on light treatments only) ranged from -0.31 to $0.37 \mathrm{~d}^{-1}$ (Table 2). Grazing on 


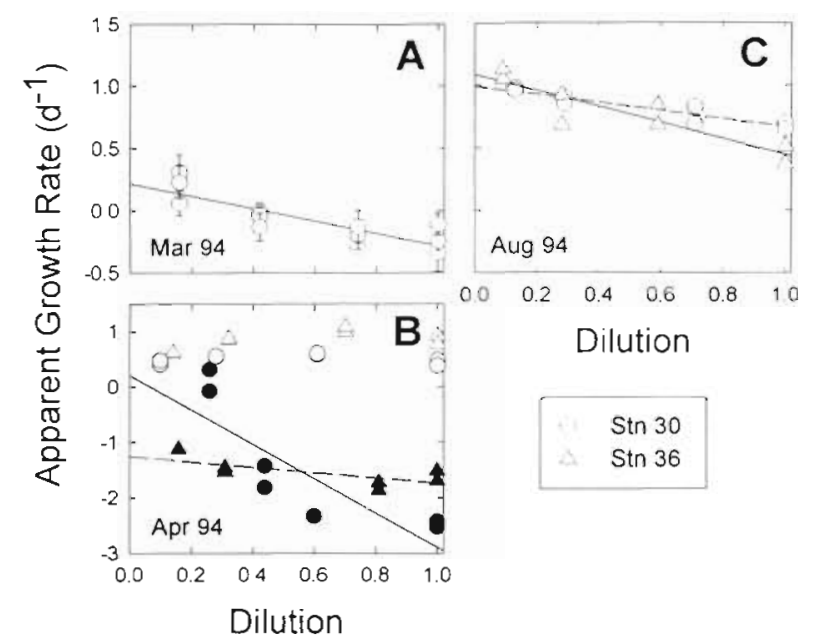

Fig. 6. Dilution plots from south San Francisco Bay showing grazing on phytoplankton as measured by chlorophyll a (open symbols) and cyanobacteria (solid symbols, no error bars) at $\operatorname{Stn} 30(\bullet, O)$ and $\operatorname{Stn} 36(\Delta, \Delta)$. Other details as in Fig. 2.

(A) 9 March 1994, (B) 15 April 1994, (C) 18 August 1994

Table 2. Summary of growth $(k)$ and of grazing $(g)$ on the phytoplankton community. Incubations were either light (L) or dark (D). N: number of bottles per experiment. Growth for dark experiments is included here for completeness, but was excluded from estimates of phytoplankton growth. Grazing was evaluated by $t$-test as non-significant (ns) or significant at the $\mathrm{p}<0.05\left({ }^{\circ}\right)$ or $\left.\mathrm{p}<0.01(\cdot)\right)$ level. If grazing was non-significant, growth was calculated from whole water treatments only

\begin{tabular}{|c|c|c|c|c|c|c|}
\hline Location & Stn & Date & $L / D$ & $\underset{\left(d^{-1}\right)}{g}$ & $\begin{array}{c}k \\
\left(d^{-1}\right)\end{array}$ & $\mathrm{N}$ \\
\hline Suisun Bay & 6 & $\begin{array}{r}8 \text { Sep } 1993 \\
8 \text { Sep } 1993 \\
6 \text { Oct } 1993 \\
6 \text { Oct } 1993 \\
8 \text { Nov } 1993 \\
8 \text { Nov } 1993 \\
7 \text { Dec } 1993 \\
7 \text { Dec } 1993 \\
17 \text { Mar } 1994 \\
19 \text { Apr } 1994 \\
17 \text { May } 1994 \\
17 \text { May } 1994\end{array}$ & $\begin{array}{l}\text { L } \\
\text { D } \\
\text { L } \\
D \\
\text { L } \\
D \\
L \\
D \\
L \\
L \\
L \\
D\end{array}$ & $\begin{array}{c}\text { ns } \\
0.37 \cdots \\
\text { ns } \\
0.28 \cdot \\
\text { ns } \\
\text { ns } \\
\text { ns } \\
\text { ns } \\
\text { ns } \\
\text { ns } \\
\text { ns } \\
0.36 \cdots\end{array}$ & $\begin{array}{r}0.09 \\
-0.26 \\
0.00 \\
0.19 \\
-0.07 \\
-0.19 \\
0.37 \\
0.19 \\
0.31 \\
0.09 \\
-0.31 \\
0.14\end{array}$ & $\begin{array}{r}8 \\
4 \\
8 \\
4 \\
8 \\
4 \\
8 \\
4 \\
12 \\
4 \\
12 \\
8\end{array}$ \\
\hline Central Bay & 18 & 19 Apr 1994 & $\mathrm{~L}$ & ns & 0.44 & 4 \\
\hline San Pablo Bay & 13 & 19 Apr 1994 & $\mathrm{~L}$ & ns & 0.30 & 4 \\
\hline Carquinez Strait & 9 & 19 Apr 1994 & $\mathrm{~L}$ & ns & 0.22 & 4 \\
\hline Chipps Island & 3 & 19 Apr 1994 & $L$ & ns & 0.30 & 4 \\
\hline Sacramento R. & 657 & 19 Apr 1994 & L & ns & 0.08 & 4 \\
\hline South Bay & 36 & $\begin{array}{r}9 \text { Mar } 1994 \\
15 \text { Apr } 1994 \\
18 \text { Aug } 1994 \\
15 \text { Apr } 1994 \\
18 \text { Aug } 1994\end{array}$ & $\begin{array}{l}\mathrm{L} \\
\mathrm{L} \\
\mathrm{L} \\
\mathrm{L} \\
\mathrm{L}\end{array}$ & $\begin{array}{c}0.51 \cdots \\
\text { ns } \\
0.33^{*} \\
\text { ns } \\
1.19^{\circ}\end{array}$ & $\begin{array}{l}0.22 \\
0.43 \\
1.00 \\
0.84 \\
1.23\end{array}$ & $\begin{array}{r}12 \\
8 \\
8 \\
8 \\
8\end{array}$ \\
\hline Tomales Bay & $\begin{array}{l}10 \\
14\end{array}$ & $\begin{array}{l}11 \text { Jul } 1994 \\
11 \text { Jul } 1994\end{array}$ & $\begin{array}{l}\mathrm{L} \\
\mathrm{L}\end{array}$ & $\begin{array}{l}0.24^{*} \\
1.14^{*}\end{array}$ & $\begin{array}{l}0.03 \\
0.43\end{array}$ & $\begin{array}{l}12 \\
12\end{array}$ \\
\hline
\end{tabular}

cyanobacteria was not significant on any of the 4 dates we measured it, whereas cyanobacteria growth ranged from 0.24 to $0.89 \mathrm{~d}^{-1}$ (Fig. 3, Table 3). Bacterioplankton grazing was significant on 2 of 3 dates measured (December 1993, May 94). When significant, grazing on bacterioplankton ranged from 0.29 to $1.02 \mathrm{~d}^{-1}$ and growth ranged from 0.05 to $0.64 \mathrm{~d}^{-1}$ (Fig, 4, Table 4).

One set of chlorophyll grazing experiments was conducted along a 6 station transect in northern San Francisco Bay in the spring of 1994 to obtain a broader view of microzooplankton grazing dynamics along the estuarine gradient. Grazing on phytoplankton was not significant at any station and growth ranged from 0.08 to $0.44 \mathrm{~d}^{-1}$ (Table 2). Phytoplankton growth rates were

Table 3. Summary of growth $(k)$ and of grazing $(g)$ on the cyanobacteria community. Incubations were either light (L) or dark (D). N: number of bottles per experiment. Growth for dark experiments is included here for completeness, but were excluded from estimates of cyanobacterial growth. Grazing was evaluated by t-test as non-significant (ns) or significant at the $p<0.05(*)$ or $p<0.01(\cdots)$ level. If grazing was non-significant, growth was calculated from whole water treatments only

\begin{tabular}{|lrrrrrr|}
\hline Location & Stn & Date & L/D & $\begin{array}{c}g \\
\left(\mathrm{~d}^{-1}\right)\end{array}$ & $\begin{array}{c}k \\
\left(\mathrm{~d}^{-1}\right)\end{array}$ & N \\
\hline Suisun Bay & 6 & 8 Sep 1993 & L & ns & 0.72 & 8 \\
& & 8 Sep 1993 & D & ns & -0.01 & 4 \\
& 6 Oct 1993 & L & ns & 0.60 & 8 \\
& 6 Oct 1993 & D & ns & 0.20 & 4 \\
& 8 Nov 1993 & L & ns & 0.25 & 8 \\
& 8 Nov 1993 & D & ns & 0.00 & 4 \\
& 17 May 1994 & L & ns & 0.89 & 12 \\
& 17 May 1994 & D & ns & 0.38 & 8 \\
South Bay & 30 & 15 Apr 1994 & L & $3.11^{*}$ & 0.22 & 8 \\
& 36 & 15 Apr 1994 & L & $0.577^{*}$ & -1.17 & 8 \\
& & & & & & \\
\hline
\end{tabular}

Table 4. Summary of growth $(k)$ and of grazing $(g)$ on the bacterioplankton community. Incubations were either light (L) or dark (D). N: number of bottles per experiment. Grazing was evaluated by $t$-test as non-significant (ns) or significant at the $p<0.05(")$ or $p<0.01(")$ level. If grazing was non-significant, growth was calculated from whole water treatments only

\begin{tabular}{|c|c|c|c|c|c|c|}
\hline Location & Stn & Date & $\mathrm{L} / \mathrm{D}$ & $\begin{array}{c}g \\
\left(d^{-1}\right)\end{array}$ & $\begin{array}{c}k \\
\left(d^{-1}\right)\end{array}$ & $N$ \\
\hline Suisun Bay & 6 & $\begin{array}{r}8 \text { Nov } 1993 \\
8 \text { Nov } 1993 \\
7 \text { Dec } 1993 \\
7 \text { Dec } 1993 \\
17 \text { May } 1994 \\
17 \text { May } 1994\end{array}$ & $\begin{array}{l}\text { L } \\
D \\
\text { L } \\
D \\
\text { L } \\
D\end{array}$ & $\begin{array}{c}\mathrm{ns} \\
\mathrm{ns} \\
0.29 \cdots \\
\mathrm{ns} \\
\mathrm{ns} \\
1.02 \cdot .\end{array}$ & $\begin{array}{l}0.07 \\
0.05 \\
0.27 \\
0.05 \\
0.30 \\
0.64\end{array}$ & $\begin{array}{r}8 \\
4 \\
8 \\
4 \\
4 \\
12 \\
8\end{array}$ \\
\hline Tomales Bay & $\begin{array}{l}10 \\
14\end{array}$ & $\begin{array}{l}11 \text { Jul } 1994 \\
11 \text { Jul } 1994\end{array}$ & $\begin{array}{l}\mathrm{L} \\
\mathrm{L}\end{array}$ & $\begin{array}{l}0.81 \cdots \\
0.69 \cdots\end{array}$ & $\begin{array}{l}1.02 \\
0.91\end{array}$ & $\begin{array}{l}12 \\
12\end{array}$ \\
\hline
\end{tabular}




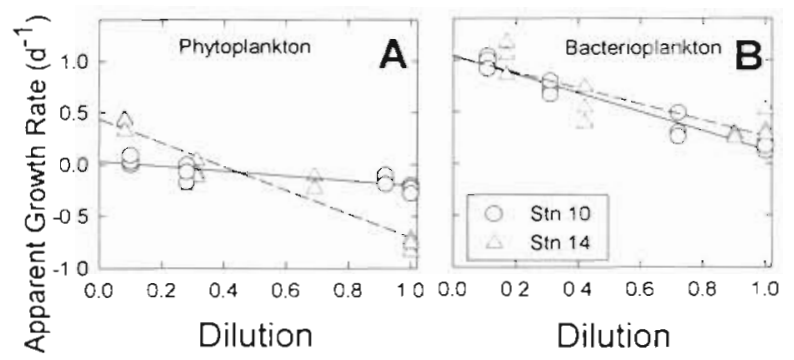

Fig. 7 Dilution plots showing grazing at Tomales Bay at Stn $10(O)$ and $\operatorname{Stn} 14(\Delta)$ on 11 July 1994. Other details as in Fig. 2. (A) Chlorophyll, (B) bacterioplankton (no error bars)

highest in Central Bay and were lowest in Suisun Bay and the Sacramento River.

In summary, in the North Bay, microzooplankton grazing was significant in 5 of the 31 measurements on all prey types. Averaging all measurements in the North Bay, grazing was $0.06 \mathrm{~d}^{-1}$ on phytoplankton ( $\mathrm{n}=$ 17), $0.00 \mathrm{~d}^{-1}$ on cyanobacteria $(\mathrm{n}=8)$, and $0.22 \mathrm{~d}^{-1}(\mathrm{n}=$ 6) on bacterioplankton. Average prey growth rates were $0.15 \mathrm{~d}^{-1}$ for phytoplankton $(\mathrm{n}=12), 0.62 \mathrm{~d}^{-1}$ for cyanobacteria $(\mathrm{n}=4)$ and $0.23 \mathrm{~d}^{-1}$ for bacterioplankton $(\mathrm{n}=6)$.

We measured microzooplankton grazing in the South Bay at Stns 30 and 36 during the spring and summer of 1994. The first experiment (9 March, Stn 30 only) was during the spring bloom; the later experiments (15 April and 18 August, both stations) were post-bloom. Grazing on phytoplankton was significant in March and August but not in April. When significant, grazing on phytoplankton ranged from 0.33 to $1.19 \mathrm{~d}^{-1}$ (Table 2). In April we also measured cyanobacteria grazing, which was significant at both stations (Fig. 6B, solid symbols, Table 3). In summary, significant microzooplankton grazing was observed in 5 of the 7 measurements made in the South Bay and on 2 of 3 dates. Grazing rates were generally higher than in the North Bay, averaging $0.41 \mathrm{~d}^{-1}(\mathrm{n}=5)$ on phytoplankton and $1.84 \mathrm{~d}^{-1}(\mathrm{n}=2)$ on cyanobacteria. Growth rates averaged $0.74 \mathrm{~d}^{-1}(n=5)$ for phytoplankton and $-0.48 d^{-1}(n=2)$ for cyanobacteria.

In Tomales Bay, grazing was statistically significant on both phytoplankton and bacterioplankton prey at both stations (Fig. 7). Grazing averaged $0.69 \mathrm{~d}^{-1}$ on phytoplankton and $0.75 \mathrm{~d}^{-1}$ on bacterioplankton. Growth averaged $0.23 \mathrm{~d}^{-1}$ for phytoplankton and $0.97 \mathrm{~d}^{-1}$ for bacterioplankton.

\section{DISCUSSION}

While it is difficult to generalize to the North Bay system, taken as a whole, it is apparent that most of the grazing experiments were not statistically significant. This is especially evident with phytoplankton and cyanobacteria, and less so for bacterioplankton. Although there are fewer data, grazing on phytoplankton and bacterioplankton was more consistent in the South Bay and Tomales Bay. The main usefulness of the results from the South Bay and Tomales Bay was to serve as a test of our experimental protocol. Before drawing conclusions of ecological significance from our results, it is important to evaluate potential artifacts which may complicate our interpretation.

\section{Effect of dilution on prey growth}

The assumption that dilution does not affect prey specific growth may be violated if prey growth becomes nutrient limited during the course of an incubation. This is of particular concern in oligotrophic environments (E. J. Lessard \& M. C. Murrell unpubl.), but is generally less critical in coastal environments which are nutrient replete. For our experiments in Suisun Bay, DIN was well above $20 \mu \mathrm{M}$ (Table 1) and changed very little over the incubation period (data not shown). While we did not measure phosphate, historical data suggest that phosphate concentrations are between 1 and $3 \mu \mathrm{M}$ with no evidence of seasonal or spatial depletion (Peterson et al, 1985, Hager \& Schemel 1992).

This assumption further implies, for photosynthetic prey, that light levels are constant across all treatments. This may not be valid in turbid environments because removal of suspended sediment may significantly alter the light attenuation in each treatment. In essence, dilute treatments will be exposed to more light than the less dilute (more turbid) treatments. Using an annual average light extinction coefficient of 5.7 from Stn 6 in Suisun Bay (equivalent to a $1 \%$ light depth of $0.8 \mathrm{~m}_{i}$ Cole \& Cloern 1984) and the width of the 1 l square incubation bottle of $9 \mathrm{~cm}$, we estimate that the most dilute treatments received about $22 \%$ more light than the undiluted treatments. These differences in turbidity among dilution treatments may cause differential phytoplankton growth rates or a photoadaptation response and this might affect our results.

This may explain why only the dark phytoplankton experiments from the North Bay had statistically significant slopes (Fig. 2A, B, F) and suggests that photoadaptation may have caused a reduction in cellular chlorophyll content of phytoplankton cells in the light treatments. If true, then we may be underestimating grazing in the North Bay using light incubations. Using only dark experiments, our grazing estimate in the North Bay would be revised upward from $0.06 \mathrm{~d}^{-1}$ ( $\mathrm{n}=$ 
17) to $0.20 \mathrm{~d}^{-1}(\mathrm{n}=5)$ which more closely balances the average phytoplankton growth of $0.22 \mathrm{~d}^{-1}$.

\section{Role of predator-prey interactions}

Predator-prey interactions such as saturated grazing (Gallegos 1989, Evans \& Paranjape 1992) or a threshold grazing response (Frost 1975, Campbell \& Carpenter 1986, Lessard \& Murrell unpubl.) may affect the interpretation of dilution experiment results. In the case of saturated grazing, predators are faced with an overabundance of prey items to consume, making it very unlikely that they are simultaneously responsible for controlling their abundance. This suggests at least a transient decoupling of production and consumption in the microbial food web. In order for predators to exert a control on prey biomass, they have to respond to changing prey abundance by changing either ingestion rate, reproductive rate or both. If prey saturation is a persistent or frequent condition in a particular environment, then predators are perhaps not adequately responding to, and hence not controlling, prey abundance.

A weak prey growth response to dilution may also occur if prey abundances are so low that predators cease feeding, thus exhibiting a threshold feeding response (Frost 1975, Campbell \& Carpenter 1986) In the context of a dilution experiment, data on a LandryHassett plot could have 2 shapes depending on whether the threshold is the ambient condition or is achieved as a result of experimental dilution. In the former case, a flat (no-slope) response would result, while in the latter case, a prey growth response (i.e. slope) would be evident in the less diluted treatments, stepping up to a flat response in more dilute treatments (see Gallegos 1989, Fig. 2B). Northern San Francisco Bay, while not a particularly productive estuary, supports a plankton biomass level which makes it doubtful that prey abundances are below threshold levels for microzooplankton in predators.

A different kind of predator-prey interaction may be important in systems where a large proportion of prey is associated with suspended particles. If predators spend much of their time grazing on the surfaces of these particles (and relatively little time searching for a new particle) then dilution with particle-free water may not reduce the grazing pressure in a direct linear fashion as predicted. This would result in a no-slope response on a Landry-Hassett plot. Because a large proportion of bacterioplankton in Suisun Bay appear to be particle associated (Hollibaugh \& Wong 1996, M. C. Murrell, J. T. Hollibaugh, M. W. Silver \& P. S. Wong unpubl.), then this may cause us to underestimate the importance of microzooplankton grazers using the dilution method.

\section{Relevance of zero grazing}

Non-significant grazing rates from dilution experiments are certainly not unique to this study. Most other published datasets, which together cover a wide range of aquatic habitats, have had at least some experiments which yielded unmeasurable grazing responses (Landry \& Hassett 1982, Landry et al. 1984, Campbell \& Carpenter 1986, Paranjape 1987, Gifford 1988, McManus \& Ederington-Cantrell 1992, Neuer \& Franks 1993, Kamiyama 1994, Lessard \& Murrell unpubl.) For example, Kamiyama (1994) has the most exhaustive published series of dilution experiments at 2 stations and for 2 size fractions on 18 dates in Hiroshima Bay, Japan. Of a total of 72 measurements, 33 (46\%) yielded statistically non-significant grazing rates. However, in this and other studies, the relevance of a zero grazing result has rarely been explored, but may have very important implications. While it is conceivable that all non-significant grazing measurements are artifacts, it is perhaps more conservative to conclude that microzooplankton are not always of primary importance in controlling prey biomass. Accepting and interpreting results of experiments which do yield measurable grazing perhaps forces us to accept and interpret results from experiments which do not yield measurable grazing. If we assume, for the sake of argument, that the measurements made in these widely varying environments are representative of natural variability, then the frequency of a non-significant grazing experiment may indicate how frequently predators are decoupled from their prey. The frequency of zero grazing is usually between about $25 \%$ (Landry \& Hassett 1982, Gifford 1988) and about 45\% (Kamiyama 1994). In the North Bay we observed non-significant grazing in $84 \%$ of our experiments, suggesting that a decoupled microbial loop may be a more persistent condition in this environment.

\section{Benthic grazing as a control of plankton biomass and production}

In simplest terms, a non-significant slope means that dilution of grazers did not affect growth of the prey community. This suggests that microzooplankton, within our means to measure it, were not an important source of phytoplankton or bacterioplankton mortality and may indicate that other sources of prey mortality play a primary role in maintaining prey abundance.

Perhaps the most important factor controlling plankton biomass in Suisun Bay is benthic grazing by the Asian clam Potamocorbula amurensis, which can have a cascading effect on the entire food web. There is strong evidence that grazing by $P$. amurensis has 
caused long-term changes in biomass and composition of phytoplankton (Alpine \& Cloern 1992) and of macrozooplankton (Kimmerer et al. 1994, Kimmerer \& Orsi 1996, Orsi \& Mecum 1996) in Suisun Bay. We do not have long-term records of bacterioplankton biomass, however Werner \& Hollibaugh (1993) demonstrated in laboratory experiments that $P$. amurensis can ingest and assimilate bacterioplankton. Their extrapolations to field conditions suggested that bacterioplankton alone may not support $P$. amurensis growth and reproduction, however we think that $P$. amurensis may be a major sink for bacterial production. Using literature values of bacterial clearance rate of $45 \mathrm{ml} \mathrm{clam}^{-1} \mathrm{~h}^{-1}$ (Werner \& Hollibaugh 1993), clam abundance of $2000 \mathrm{~m}^{-2}$ (Nichols et al. 1990), and Suisun Bay average water column depth of $3.2 \mathrm{~m}$ (Jassby et al. 1993), we calculate that the $P$. amurensis community may clear $68 \%$ of the bacteria from the water column $\mathrm{d}^{-1}$. In other words, bacterioplankton would have to grow at $0.68 \mathrm{~d}^{-1}$ to maintain level abundances which is outside the range $\left(0.05\right.$ to $\left.0.64 \mathrm{~d}^{-1}\right)$ which we measured with the dilution method. In hindsight, it is perhaps less surprising that microzooplankton may have limited importance in controlling phytoplankton or bacterioplankton in this sort of system.

The above indicates that Potamocorbula amurensis may cause decoupling of the microbial loop in northern San Francisco Bay by directly consuming microzooplankton prey, however they may also disrupt coupling by directly ingesting microzooplankton. Whichever mechanism (or both combined) is significant, we would expect microzooplankton abundances to be depressed in Suisun Bay. Unfortunately, we have very little microzooplankton abundance data from this turbid environment to support this hypothesis. If we assume that roughly half of the total nanoflagellates were heterotrophic then we might expect 800 flagellates $\mathrm{ml}^{1}$ (range 300 to 1200). This estimate of abundance, while admittedly crude, is on the lower end of estimates from other coastal environments (Sanders et al. 1992).

\section{Microzooplankton and the microbial loop}

The relative importance of microzooplankton to overall food web structure and function depends on the characteristics of the system under study. For example, in the oligotrophic open ocean, microzooplankton are a critical source of ammonium which in turn supports regenerated production (Goldman \& Caron 1985, Goldman et al. 1985). Such a source of ammonium is not likely critical in a system that is replete with nutrients such as San Francisco Bay or it may only be important at certain times of the year, such as in South Bay late in a spring bloom cycle after nutrients have been depleted. A second critical function attributed to microzooplankton is to control the biomass of prey and thus prevent their accumulation (Fenchel 1982, McManus \& Fuhrman 1988). Our results indicate a weak link between microzooplankton and their prey in the North Bay. A third function of microzooplankton is to serve as a trophic link to higher level consumers. Given the apparent dominance of benthic grazing in the North Bay, it is likely that microzooplankton production, like the macrozooplankton, is food limited and thus microzooplankton have limited importance as a conduit for carbon flow to higher trophic levels.

Acknowledgements. This study was supported by California Department of Water Resources, Interagency Ecological Program B-59329, C4-01618 and B80517. We also acknowledge support from Sigma Xi, the Scientific Research Society, Grants-in-Aid of Research. We are very grateful for the generous support provided by the USGS, San Francisco Bay Estuary Project, in particular Brian Cole, Scott Conard, Francis Parchaso and Byron Richards for allowing us to participate on RV 'Polaris' cruises and for logistical and lab support. Many thanks to Jane Caffrey for nutrient analyses and numerous fruitful discussions. Mary Silver and 3 anonymous reviewers provided many helpful comments and suggestions on earlier versions of this manuscript.

\section{LITERATURE CITED}

Alpine AE, Cloern JE (1992) Trophic interactions and direct physical effects control phytoplankton biomass and production in an estuary. Limnol Oceanogr 31:68-78

Ambler JW, Cloern JE, Hutchinson A (1985) Seasonal cycles of zooplankton from San Francisco Bay. Hydrobiologia 129:177-198

Azam F, Fenchel T, Field JG, Gray JS, Meyer-Reil LA, Thingstad F (1983) The ecological role of water-column microbes in the sea. Mar Ecol Prog Ser 10:257-263

Berninger UG, Caron DA, Sanders RW, Finlay BJ (1991) Heterotrophic flagellates of planktonic communities, their characteristics and methods of study. In: Patterson DJ, Larsen $\mathfrak{J}$ (eds) The biology of free-living heterotrophic flagellates. Clarendon Press, Oxford, p 39-56

Bower CE, Holm-Hansen T (1980) A salicylate-hypochlorite method for determining ammonia in seawater. Can J Fish A quat Sci 37:794-798

Campbell L, Carpenter EJ (1986) Estimating the grazing pressure of heterotrophic nanoplankton on Synechococcus spp. using the sea water dilution and selective inhibitor techniques. Mar Ecol Prog Ser 33:121-129

Cloern JE (1991) Tidal stirring and phytoplankton bloom dynamics in an estuary. J Mar Res 49:203-221

Cloern JE, Cole BE, Wong RLJ. Alpine AE (1985) Temporal dynamics of estuarine phytoplankton: a case study of San Francisco Bay. Hydrobiologia 129:153-176

Cole BE (1989) Temporal and spatial patterns of phytoplankton production in Tomales Bay, California, USA. Estuar Coast Shelf Sci 28:103-115

Cole BE, Cloern. JE (1984) Significance of biomass and light availability to phytoplankton productivity in San Francisco Bay. Mar Ecol Prog Ser 17:15-24 
Cole BE, Cloern JE (1987) An empirical model for estimating phytoplankton productivity in estuaries. Mar Ecol Prog Ser 36:299-305

Cole BE, Thompson JK, Cloern JE (1992) Measurement of filtration rates by infaunal bivalves in a recirculating flume. $\checkmark$ Mar Res 113:219-225

Evans GT, Paranjape MA (1992) Precision of estimates of phytoplankton growth and microzooplankton grazing when the functional response of grazers may be nonlinear. Mar Ecol Prog Ser 80:285-290

Fenchel TM (1982) The ecology of heterotrophic microflagellates. IV. Quantitative occurrence and importance as bacterial consumers. Mar Ecol Prog Ser 9:35-42

Frost BW (1975) A threshold feeding response in Calanus pacificus. Limnol Oceanogr 20:257-263

Gallegos CL (1989) Microzooplankton grazing on phytoplankton in the Rhode River, Maryland: non-linear feeding kinetics. Mar Ecol Prog Ser 57:22-33

Gifford DJ (1988) Impact of grazing by microzooplankton in the northwest arm of Halifax Harbour, Nova Scotia. Mar Ecol Prog Ser 47:249-258

Goldman JC, Caron DA (1985) Experimental studies on an omnivorous microflagellate: implications for grazing and nutrient regeneration in the marine microbial food chain Deep Sea Res 32:899-915

Goldman JC, Caron DA, Andersen OK, Dennett MR (1985) Nutrient cycling in a microflagellate food chain: I. Nitrogen dynamics. Mar Ecol Prog Ser 24:231-242

Gundersen K, Bratbak G, Heldal M (1996) Factors influencing the loss of bacteria in preserved seawater samples. Mar Ecol Prog Ser 137:305-310

Hager SW (1993) Dissolved nutrient and suspended particulate matter data for the San Francisco Bay estuary October 1988 through September 1991. OFR 93-57, United States Geological Survey, Washington, DC

Hager SW, Schemel LE (1992) Sources of nitrogen and phosphorus to northern San Francisco Bay. Estuaries 15:40-52

Hobbie JE, Paley RJ, Jasper S (1977) Use of nuclepore filters for counting bacteria by epifluorescence microscopy. Appl Environ Microbiol 33:1225-1228

Hollibaugh JT, Wong PS (1996) Distribution and activity of bacterioplankton. In: Hollibaugh JT (ed) San Francisco Bay: the ecosystem. Pacific Division, American Association for the Advancement of Science, San Francisco, p 263-288

Jassby AD, Cloern JE, Powell TM (1993) Organic carbon sources and sinks in San Francisco Bay: variability induced by river flow. Mar Ecol Prog Ser 95:39-54

Kamiyama T (1994) The impact of grazing by microzooplankton in northern Hiroshima Bay, the Seto Inland Sea, Japan. Mar Biol 119:77-88

Kimmerer WJ, Gartside E, Orsi JJ (1994) Predation by an introduced clam as the likely cause of substantial declines in zooplankton of San Francisco Bay. Mar Ecol Prog Ser 113:81-93

Kimmerer WJ, Orsi JJ (1996) Changes in the zooplankton of the San Francisco Bay estuary since the introduction of the clam Potamocorbula amurensis. In: Hollibaugh JT (ed) San Francisco Bay: the ecosystem. Pacific Division, American Association for the Advancement of Science, San Francisco, p 403-424

Landry MR, Haas LW, Fagerness VL (1984) Dynamics of microbial plankton communities: experiments in Kaneohe
Bay, Hawaii. Mar Ecol Prog Ser 16:127-133

Landry MR, Hassett RP (1982) Estimating the grazing impact of marine micro-zooplankton. Mar Biol 67:283-288

Lessard EJ (1991) The trophic role of heterotrophic dinoflagellates in diverse marine environments. Mar Microb Food Webs 5:49-58

McManus GB, Ederington-Cantrell MC (1992) Phytoplankton pigments and growth rates, and microzooplankton grazing in a large temperate estuary. Mar Ecol Prog Ser 87 : $77-85$

McManus GB, Fuhrman JA (1988) Control of marine bacterioplankton populations: measurement and significance of grazing. Hydrobiologia 159:51-62

Neuer S, Franks PJS (1993) Determination of ammonium uptake and regeneration rates using the seawater dilution method. Mar Biol 116:497-505

Nichols FH, Thompson JK, Schemel LE (1990) Remarkable invasion of San Francisco Bay (California, USA) by the Asian clam Potamocorbula amurensis 2. Displacement of a former community. Mar Ecol Prog Ser 66:95-101

Orsi JJ, Mecum WL (1996) Food limitation as the probable cause of a long-term decline in the abundance of Neomysis mercedis the opossum shrimp in the Sacramento-San Joaquin estuary. In: Hollibaugh JT (ed) San Francisco Bay: the ecosystem. Pacific Division, American Association for the Advancement of Science, San Francisco, p 375-402

Paranjape MA (1987) Grazing by microzooplankton in the eastern Canadian arctic in summer 1983. Mar Ecol Prog Ser 40:239-246

Peterson DH, Smith RE, Hager SW, Harmon DD, Herndon RE, Schemel LE (1985) Interannual variability in dissolved inorganic nutrients in Northern San Francisco Bay Estuary. Hydrobiologia 129:37-58

Pomeroy LR (1974) The ocean's food web, a changing paradigm. BioSci 24(9):499-504

Porter KG, Feig YS (1980) The use of DA.PI for identifying and counts of aquatic microflora. Limnol Oceanogr 25:943-948

Sanders RW, Caron DA, Berninger UG (1992) Relationships between bacteria and heterotrophic nanoplankton in marine and fresh waters: an inter-ecosystem comparison. Mar Ecol Prog Ser 86:1-14

Sherr BF, Sherr EB (1994) Bacterivory and herbivory: key roles of phagotrophic protists in pelagic food webs. Microb Ecol 28:223-235

Sherr EB, Sherr BF, Paffenhöfer GA (1986) Phagotrophic protozoa as food for metazoans: a 'missing' trophic link in marine pelagic food webs. Mar Microb Food Webs 1: $61-80$

Stoecker DK, Capuzzo JM (1990) Predation on protozoa: its importance to zooplankton. J Plankton Res 12:891-908

Strickland JDH, Parsons TR (1972) A practical manual for seawater analysis. Fish Res Bd Can Bull 167

Turley CM, Hughes DJ (1992) Effects of storage on direct estimates of bacterial numbers of preserved seawater samples. Deep Sea Res 39:375

Turley CM, Hughes DJ (1994) The effect of storage temperature on the enumeration of epifluorescence-detectable bacterial cells in preserved sea-water samples. J Mar Biol Assoc UK 74:259-262

Werner I, Hollibaugh JT (1993) Potamocorbula amurensis: comparison of clearance rates and assimilation efficiencies for phytoplankton and bacterioplankton. Limnol Oceanogr 38:949-964

Submitted: April 4, 1997; Accepted: November 20, 1997

Proofs received from author(s): March 20, 1998 